\title{
Teachers Professional Development at Public Campuses: Attitude and Practice
}

\author{
Dinesh Panthee
}

\begin{abstract}
Teacher Professional Development is a process of improving both the teachers' academic excellence and acquisition of greater competence and efficiency. It helps to develop various kinds of professional skills, knowledge, techniques, and ICTs used in teaching and learning. The purpose of this study was to find out the attitude and practice of teachers on teacher professional development in public campuses. It also aimed to find out the existing policies and provisions regarding the modalities of teachers' professional development at public campuses. This study was based on a qualitative research design with phenomenological methods. The participants of the study were two teachers of the different public campuses of Rupendehi district. They were selected using a purposive sampling method. The data were collected by taking indepth interviews of the participants using unstructured guideline questions. The interview questions were directed to the participant's experiences, feelings, beliefs, and convictions about the theme in the research questions. The findings of this study revealed that teachers' professional development is the most important factor for improving teachers professionally, academically, and technically but professional development activities of the public campuses are not satisfactory.
\end{abstract}

Keywords: Professional development, public campuses, lifelong learning, constructivism model, and instructional techniques.

\section{Introduction}

I used the term teacher professional development here to refer to teacher education. It is a growing field that focuses on the professional growth and strengths of teachers. The term teacher development is the process of becoming the best type of teacher. It starts from the beginning and continues until retirement professionally. Teacher professional development (TPD) intends to increase the skills, knowledge, or understanding of teachers and their effectiveness in schools. It maintains a certain level of professionalism and it has a positive impact on teachers' beliefs and practices. Fullan

\footnotetext{
${ }^{*}$ Mr. Panthee is a M.Phil scholar of Graduate school of Education, Tribhuvan University. He has worked in the field of education. Currently he is the Assistant Professor of English Language Education. at Sahid Narayan Pokharel Campus, Rupandehi.
} 
(1995) mentions that TPD is "the total of formal and informal learning pursued and experienced by the teacher in a compelling and dynamic change" p. 265. Tomlinson (1999) defines TPD as an activity designed to promote learning which is the way of producing professional teachers. Bredeson (2002) presents three interdependent concepts of TPD as learning, engagement, and involvement. It is an activity that develops an individual's skills, knowledge, expertise, and other characteristics as a teacher. TPD provides teachers with opportunities to explore new roles, develop new instructional techniques, refine their practice, and broaden themselves (Komba \& Nkumbi, 2008). It is multi-dimensional: content, process, and context. This paper presents TPD as a critical component for the teachers of public campuses of Nepal. Teacher professional development is based on constructivism model rather than transmission orientation model. This theory is compatible with the behavioristic view of learning, in which both curriculum and instruction are broken down into small, sequential steps dictated by the teacher. TPD requires the acquisition of new skills, knowledge, attitudes, values, and a wide variety of teaching strategies, to enable students to construct their knowledge. The brain behind this kind of philosophical approach is best described in Confucius, a Chinese philosopher's quote: "I hear, and I forget. I see, and I remember. I do, and I understand" (Adom, Yeboah and Ankrah, 2016). A teacher conceived as a reflective practitioner. Darling-Hammond and McLaughlin (1996) assert that teacher development must focus on deepening teachers' understanding of the processes of teaching and learning, as well as of the students they teach. Richards and Farrell (2005) present different activities like engaging in selfreflection and evaluation, developing specialized knowledge and skills about many aspects of teaching, and developing collaborative relationships with other teachers for teacher development. Hence, teacher professional development should shift from a behaviouristic towards a constructivist approach. This paper presents professional development as a critical component for the teachers of public campuses of Nepal. Teacher Professional Development status in Public Campuses of Nepal

The public campuses are unable to offer better TPD facilities for their teachers and do not have very sharp vision and policies regarding the professional development of the faculty members. TPD has been realized as a powerful approach to implement student-centered activity for education in the twenty-first century (Pokhrel, 2016). Limited facilities, lack of high esteem in the society, unnecessary political interference are the disturbances for TPD on public campuses. Reflecting on my fifteen years of experience of teaching in a public campus in Rupandehi, I realized that very few teachers from public campuses have got the chance for professional development activities. Being a campus chief of a public campus I have an understanding that the stakeholders are not positive towards the professional development of their faculties. 
Even though there are certain provisions for the teacher professional development activities in their campus bylaw the CMC and Campus administrations are not positive towards it. They see everything in their political eyes and do not support them. In the same way, most of the faculty members are school teachers who take this job as secondary so they are not proactive towards their development. For this reason, the faculty members who have been teaching public campuses lack the opportunities for their professional development. Stakeholders neglect them, so they are dissatisfied with their job. This dissatisfaction has been helping to reduce the quality of education on public campuses in Nepal.

The teachers of public campuses have not been getting enough TPD facilities. It is necessary to find out whether the public campuses are delivering such an opportunity to the teachers or not. How often do teachers get the opportunity to participate in career development and TPD activities? And what provisions are made for TPD and how they practiced at public campuses? To answer these questions, I attempted to find out the provision of teacher professional development, its implementation strategy, status, and means of TPD adopted by public campuses really in practice or not. Since a huge number of students are dependent on public campuses to shape their careers and direct their future. If the programs of such campuses run without the TPD plan, then the future of public campuses may fall at risk. So, there requires specific research regarding TPD at public campuses of Nepal. A little research work has been carried out about TPD on public campuses. Many kinds of research have been carried out for TPD of school-level teachers in Nepal. But a few on TPD of the teachers of public campuses of Nepal. For this reason, I had selected the present research topic to mitigate the gap in it. The main purpose of this study was to find out the attitude and practice of teachers on teacher professional development in public campuses. It also aimed to find out the existing policies and provisions regarding the modalities of TPD at public campuses. It tried to explore the strategies for teacher professional development in public campuses of Nepal. In addition to this, I have formulated the following research questions for this study;

1. How do the teachers of public campuses perceive the teacher's professional development?

2. How do they practice the activities of teacher professional development during involvement in teaching and learning on campus?

3. What provisions and facilities are available for teachers to develop their professionalism in public campuses? 


\section{Methodology}

This study was based on a qualitative research design. It is a form of inquiry that explores phenomena in their natural settings. It uses multi-methods to interpret, understand, explain, and bring meaning to them. Creswell (2003) states that a qualitative approach is one in which the inquirer often makes knowledge claims based primarily on a constructivist perspective. I used a phenomenological method that studies the structure of various types of experience ranging from perception, thought, memory, imagination, emotion, desire, and volition to bodily awareness, embodied action, and social activity, including linguistic activity (Smith, 2004). The research site was Rupandehi district of Nepal which was selected purposely.

For locating the research participants, first of all, I enlisted all the public campuses in Rupandehi District. After that, I selected two Campuses by using a purposive method then I chose two teachers; one teacher from each campus as participants based on my judgments and the purpose of the research. Finally, I took an in-depth interview with the selected participants by using unstructured guideline questions. My interview questions were directed to the participant's experiences, feelings, beliefs, and convictions about the theme in the research questions. I audio and video recorded all interviews with the permission of interviewees. I gave different codes for the participants that were identified by the alphabet characters 'MM' and 'MJ'. I store the data which includes audio recordings, field notes, and filing of hard copy documentation. Field notes are a secondary data storage method in qualitative research. Because the human mind tends to forget quickly, field notes by the researcher are crucial in qualitative research to retain data gathered (Lofland \& Lofland, 1999). The interview transcriptions and field notes were also stored electronically on hard drives. As soon as possible, after each interview, I listened to the recording and transcribed keywords, phrases, and statements to allow the voices of research participants to speak. Regarding the tools, for data collection, I used unstructured guideline questions that were prepared based on research questions. I also used field notes and recordings. The collected data were analyzed descriptively developing themes based on the response of the participants. I used the thematic analysis in this paper as a descriptive approach with a focus on lived experience, which refers to our experiences of the world.

The study was limited to the two public campuses only which are under the Public Campus Association of Rupandehi district. It was only limited to find out the perception and the practice of TPD on public campuses of Nepal. The participants were only two teachers from the selected campuses of Rupandehi. 


\section{Results and Discussion}

I used the 'phenomenological study' method for data collection. Researchers who used phenomenology are reluctant to prescribe techniques Holloway (1997). I intended to gather data regarding the perspectives of research participants about the phenomenon of TPD. My questions were "directed to the participant's experiences, feelings, beliefs and convictions about the theme in question" (Welman \& Kruger, 1999, p. 196) as cited in (Groenewald, 2004). I decided to analyze and interpret the collected data qualitatively by making the theme based on interviews, field notes, and other relevant literature. I have presented this section by making four themes based on the research questions.

\section{Teaching Experiences in Public Campuses}

Teaching is a challenging job. It is the process of attending to people's needs, experiences, feelings, and intervening (Jackson, 2019). Indeed, teachers are key to the success of reform initiatives, as they are ultimately the ones in charge of enacting these initiatives within the classroom (Guskey, 2002). Here I endeavored to find out the teaching experiences of the participants on public campuses of this research. My first respondent 'MM' is an energetic and young faculty member of her campus. She has been teaching on her campus for bachelor and master level for 20 years. The second respondent 'MJ' is also an enthusiastic and dedicated faculty of his campus. He has been teaching on this campus for 19 years. He is teaching in the bachelor's and master's programs of TU. Both are happy to adopt teaching as an academic profession. But they feel guilty when they see the discrimination among the faculties respondent 'MJ' said 'Discrimination on the community campus is heart-breaking'. This means discrimination on community campuses is very upsetting. Such types of activities are often found on most public campuses. He further added that two teachers started teaching on the campus on the same day but one of them got an appointment letter two months ago and the other got two months later. This type of discrimination demoralizes teachers. Even though whatever discrimination is there on the public campus they both are happy with their profession. My respondent 'MM' said she feels great about teaching local students. She is very happy about getting opportunities to assist in the educational upliftment of local level students. So they are satisfied with their profession even though there are different problems on their campuses. My respondent 'MM' said 'I feel great while adopting the academic profession.' Psychologically the participants are satisfied while adopting an academic profession. Teacher job satisfaction has been recognized as extremely important for implementing any type of education reform, for involving the teacher in life-long learning, for the quality of the teaching-learning process, and 
satisfaction with life in general. Teachers are the key elements of whole teachinglearning activities (Mizell 2010).

\section{Teacher's Professional Development as a Lifelong Process of Teachers' Learning}

Teacher professional development is the development of a teacher's qualification and efficiency. A teacher who perceives professional development positively is eager to attain new knowledge, skills, attitudes, values, and dispositions (Komba \& Nkumbi, 2008). So the teachers of public campuses should develop various kinds of teacher's professional qualities to develop their careers. In this regard respondent, 'MM' expressed her idea as 'Teachers' professional development is quite important for teachers. When teachers are professionally developed, they can teach their students as per the needs of the student and their society. If they are not professionally developed, they can't be influential teachers to their students'. She said 'TPD is a way to acquire new skills and knowledge in the teaching profession'. TPD helps any teacher to conduct excellent educational activities by making him or her updated. "Teachers are active, thinking decision-makers who make instructional choices by drawing on complex practically-oriented, personalized, and context-sensitive networks of knowledge, thoughts, and beliefs" (Borg, 2003, p. 81).

TPD helps update the teachers in line with changes in the curriculum and enables them to serve pupils better and improve the standard of performance. In the same way, my second participant gave more emphasis on TPD as a way to help teachers to update formally by developing new knowledge and skills. So TPD is a scheme to acquire new skills and knowledge in the teaching profession. According to Bredeson (2002) "learning opportunities that engage educators' creative and reflective capacities in ways that strengthen their practice". So there is a great importance of TPD in the teachers of the public campuses in the sense that it helps the teacher to develop various kinds of professional skills, knowledge, new techniques of teaching, the modern technology of teaching. It encourages teachers to explore their own beliefs and thinking processes and to examine how these influence their classroom practice Richards \& Farrell, (2005). The teacher can use new ideas and methodologies in the classroom if they are updated through different activities of TPD.

In this context respondent, 'MJ' expressed his opinion as; 'It is important for teachers because it offers them an opportunity to explore new ways of teaching and learning'. It shows that there is very much importance of TPD in the teachers because it helps improve the teacher professionally, academically, and technically. It is an aspect, which encourages the teachers to do many kinds of research in the academic fields. Likewise, respondent 'MM' explained the importance of teachers' professional 
development is to explore new methods and techniques of teaching and learning. Teachers need to revise and update their knowledge and skills. In the same way respondent, 'MJ' has taken Teacher's professional development as an important tool for teachers to develop the practical skill for teaching effectively and managing the different aspects of the teaching profession. We can conclude both respondents' explanations as TPD is important and lifelong learning activities for teachers (DarlingHammond, Hyler, \& Gardner, 2017) because of quality education, personal development, leadership development, updating, for research writing, and proper use of technology.

\section{Teachers Attitudes and Perception towards Professional Development}

TPD is an essential part of any teaching faculty for getting more skills, gaining confidence, and competence. To do effective teaching, the teacher should be trained, excellent as well as up-dated according to the change of time. In this sub-topic, I aimed to stumble on the concept of teacher professional development from both participants of this research. TPD requires continuity in learning emphasizing need-based planning, exploring teachers' strengths and weaknesses. The respondent 'MM' said "of course! Teachers' professional development activities are inevitable. They help teachers enhance and arouse the students' learning pace and efficiency'. It helps enable teachers to move with changes in science and technology. In this concern, my respondent 'MJ' believed that TPD inspires teachers to be innovative in teaching. Respondent 'MM' claimed 'professional development inspires us to be more creative and innovative'. In the same way respondent, 'MJ' argued that Teacher professional development is the most important part of teaching-learning activities which foster the teacher to become innovative and updated. He said ' of course, it is inevitable for teachers. It helps us to build up confidence and quality education. But, it is not given for public campus faculty time and again'. He added TPD is not only a matter of reading and teaching but also of formally updating oneself by being active in research in various fields. Both respondents agreed with the necessity of TPD for the teachers that include teachers' training, seminars, workshop, teachers' discussion program, research works, etc.

The teachers should be self-conscious about their professional development by doing various kinds of academic works. It is an action that develops the skill, efficiency, and prestige of teachers. About this, my respondent 'MJ' emphasized that teachers should always be up-to-date, formally, and informally refine themselves not only to read and teach but also to acquire higher-level qualifications. It is fruitful for the development of the social, economic, and educational status of the teachers. Choy and Chua, (2019) state that TPD reinforced the need for promoting growth and development 
amongst teachers, endorsing greater recognition for excellence in teaching and leadership, establishing high standards for professional teaching status, and reducing timelines for improvement, to enhance student learning, growth, and achievement, and school performance. It is fruitful for the development of the social, economic, and educational status of the teachers (Zeng \& Day, 2019). It is an action that develops the skill, efficiency, and prestige of teachers.

TPD is an action, which helps the teacher to solve the practical problems of teaching and learning. So, every teacher should be involved in their development. In this subsection, I made an effort to hit upon the teachers participating in professional development activities and further study. These activities are the most important aspects of TPD. Both respondents argued that most of the teachers are not interested in TPD. They don't give attention to their professional development. Respondent 'MM' said 'they don't have much desire and liability so fewer faculties are participating in such programs'. It shows that the teachers are not concerned about their professional development. It is also found that the teachers themselves are not proactive in their professional development. They tend to have an allowance oriented attitude rather than skills enhancement expectations (Ghimire, 2019). Teachers of public campuses need to participate in the activities of TPD then only they could compete with other institutions' teachers.

\section{Provisions and Practices for Teacher Professional Development in Public Campuses}

Most successful educational organizations regard the professional development of their faculties as a matter of high priority. Various provisions are made by the campuses as mentioned in their bylaw. They are far better in formulating the provisions for which indeed seems motivational in policy, plan, and regulation formulation as well (Ghimire, 2019). But the application of TPD facilities in real context is too weak in comparison to their provision and policy formulation. Respondent 'MM' said 'our campus has also made some provisions for the professional development of teachers. It has made a policy to permit teachers for their further studies, to assist them to carry out research works and to organize different training for its implementation in classroom teaching'. She added that whatever is written on campus bylaw the administration and campus management committee do not have a positive attitude towards it. As different provisions are provisioned in campus bylaw but there lacks in reality. They show the economic crisis and deny to do the decision in favor of the teachers. The state and stakeholders also have discriminatory attitudes toward public campuses and their faculties. Support of campus management is crucial for promoting teacher development and high-quality education. If faculty members are empowered 
they will be able to play their social and technical roles more efficiently. But in the practice of public campuses; we don't find good practice for TPD. In this regard respondent, 'MJ' has a bitter experience with it and he said that 'It has been four or five years waiting for study leave but the campus has not given any attention towards it. I'm worried about whether the job will be continued or not when I go to study.' Eight months have passed since I applied for my Ph.D. study leave, but no decision has been made yet.' Teacher professional development is not only the entity of a teacher but also the matter of institutions. TPD helps the improvement of the performance of the campus as a whole, that is, to make it more successful, attract more students, and achieve better learning outcomes (Richards \& Farrell, 2005). But we don't find a positive environment for TPD in public campuses in Nepal. My respondent 'MJ' has expressed his grief ‘ Campus commitments have not been implemented in practice. Some people who are close to the administration have been helped, but other teachers have not been motivated'. Campus commitments have not been implemented in practice. Some teachers who are close to the administration have been helped, but other teachers have not been motivated for TPD and their further study. My respondent 'MM' said 'नटेक्नेहाँगोछनसमाउनेडालोछ' It means 'there is neither a branch to stand on nor a branch to hold.' It shows the bitter truth towards TPD and further study of the faculty members of the public campus. Teachers expect it to be demand based in practice not only in policy (Pokhrel, \& Behera, 2016). Even though various provisions are made at public campuses for their teachers using regular activities, research opportunities, study leave and various projects, etc. (Shrestha, 2012). But such facilities have not been implemented in real situations they are demotivated for TPD.

As I believe through my experience of teaching at public campuses that teachers' professional development is either advancement of teachers in the field of teaching or improving teachers professionally, academically, and technically. In the same way, my respondents took TPD as a process of enabling teachers to move with changes in science and technology, and as a new way of acquiring new methods of teaching. They perceived it as academic advancement as well as development in the profession. In their opinion, they assured that TAD enables teachers to become professionals, to realize their potential as teachers, to move with changes in science and technology, and enables them to serve students better by improving the standard of teaching (Powell, \& Bodur, 2019). I also further believe that in the process of improving themselves they also gain confidence and self-esteem.

\section{Conclusion}


Teachers' professional development for faculty members of public campuses is necessary for updating according to modern time and technology. Only TPD is such an aspect that encourages the teachers to do many types of research in the academic fields. It provides essential support for the teachers in the public campuses to revise and bring up to date their knowledge and teaching skills as well as assessment skills. It also helps teachers be motivated and perform better than before. The finding of the study showed that the TPD activities of the teachers of public Campuses are not satisfactory. The concerned stakeholders of public campuses neglected the necessity of TPD for their faculty members even though many provisions are provisioned on the campus by law. They are demotivated towards their professional development because they are not getting any instinctive and opportunities for their career advancement. I believe that teachers are the best leaders of society, institutions, and classes for this special characteristic. They required professional development to develop various skills of leadership development and coordinating skills from its activities.

As my perception; my respondents perceived TPD as an important activity because it improves the teacher professionally, academically, and technically. This study found that the teachers of public campuses perceive TPD as an essential part of their career enhancement. They have been trying to practice the activities of TPD during involvement in teaching and learning on campus. There is inadequate support and motivation for TPD. They believed that TPD helps them to achieve high standards of teaching and keep them updated. It allows them to react appropriately to the challenges brought about by advancements in science and technology, and to get promoted to higher ranks in their career.

The provisions made for teachers to develop their professionalism by public campuses are only limited in the paper and into the formal commitment. The reason for the absence of such opportunities is because of the great financial problem of the sustainability of campuses and attitude towards TPD. They are improving some prompts and trying to focus on the implementation of their provisions which helps to grow teacher professionalism and quality education. But, stakeholders are being either disturbed or worried by unnecessary political influences that need to be taken into consideration by educational authorities and different level governments. The CMC and administration are not very responsible and active in implementing their policies and provisions in reality. CMC of public campuses must be thoughtful to address the minimum provisions provisioned in their campus bylaw. They must provide moral and economical support to their teachers to transform their professional inputs into their classroom as per the commitment exposed through legal provisions. Campus administration, Campus Management Committee, Public campus Teacher Association, Public Campus Association, RMC, and concerned authority must be oriented for the 
specific, planned, and scheduled TPD activities through prior acceptance and cooperation. Each public campus must prepare a comprehensive master plan for TPD including policies, strategies, and implementation mechanisms taking into consideration the challenges and possibilities. We can then expect that this initiative can help to improve quality of education in Nepal.

\section{References}

Adom, Yeboah \& Ankrah, (2016). Constructivism philosophical paradigm: implication for research, teaching, and learning. Global Journal of Arts Humanities and Social Sciences, 1-9. Retrieved from https://www.researchgate.net/

Borg, S. (2003). Teacher cognition in language teaching: A review of research on what language teachers think, know, believe, and do. Language teaching, 36(2), pp. 81-109. https://doi.org/10.1017/S0261444803001903

Bredeson, P. (2002). Professional development of university teachers. London: Flamer Press.

Choy, W. K., \& Chua, P. M. (2019). Professional development. School leadership and educational change in Singapore, pp. 69-86. Springer, Cham. Retrieved from https://www.researchgate.net/

Creswell, J. W. (2003). Qualitative, quantitative, and mixed methods approach. New York: Sage publication

Darling-Hammond, L., \& McLaughlin, M. W. (1996). Policies that support teacher development in an era of reform. Teacher learning: New policies, new practices, pp. 202-218. Retrieved from https://www.researchgate. net/

Darling-Hammond, L., Hyler, M. E., \& Gardner, M. (2017). Effective teacher professional development. Retrieved from https://scholar.google.com/scholar

Fullan, M. (1995). The role of the principal in school reform. New York: Teachers College Press.

Ghimire, N. B. (2019). Realities of teachers' professional development in public campuses of Tribhuvan University. NUTA Journal, Vol. 6(1-2), pp. 32-38.

Groenewald, T. (2004). A phenomenological research design is illustrated.

International journal of qualitative methods, Vol. 3(1), pp. 42-55. Retrieved from http://creativecommons.org/licenses/by/2.0

Holloway, I. (1997). Basic concepts for qualitative research. New Jersey: WileyBlackwell.

Jackson, B, (2019). What is teaching? A definition and discussion, infed.org: education, community-building, and change. Retrieved from https://infed.org/mobi/what-isteaching/ 
Komba, W. L., \&Nkumbi, E. (2008). Teacher professional development in Tanzania: Perceptions and practices. Journal of international cooperation in education, Vol. 11(3), pp. 67-83. Retrieved from https://scholar.google.com/scholar

Lofland, J., \&Lofland, L. H. (1999). Data logging in observation: Field notes. Qualitative research, 3. Retrieved from https://scholar.google.com/scholar

Mizel, H. (2010). Why professional development matters, Locust St. Oxford University Press.

Pokhrel, T. R., \& Behera, S. K. (2016). Expectations of teachers from the teachers' professional development programs in Nepal. American Journal of Educational Research,Vol. 4(2), pp. 190-194. Retrieved from https://scholar.google.com/scholar

Guskey, T. R. (2002). Professional development and teacher change. Teachers and teaching, Vol. 8(3), 381-391. Retrieved from https://scholar.google.com/scholar

Powell, C. G., \& Bodur, Y. (2019). Teachers' perceptions of an online professional development experience: Implications for a design and implementation framework. Teaching and Teacher Education, Vol. 77, pp. 19-30. Retrieved from https://scholar.google.com/scholar

Richards, J. C., \& Farrell, T. S. C. (2005). Professional development for language teachers: Strategies for teacher learning. London: Cambridge University Press.

Shrestha, R. (2012). Teacher Professional Development (TPD) program: Boon or bane? Available in http://neltachoutari.wordpress.com/2012/09/01/teacherprofessional-development-tpd-program-boon-or-bane.

Smith, D. W. (2004). Mind World: Essays in phenomenology and ontology. Cambridge University Press. Retrieved from https://scholar.google.com/scholar

Tomlinson, C. A., Brighton, C., Hertberg, H., Callahan, C. M., Moon, T. R., Brimijoin, K., \&Reynolds, T. (2003). Differentiating instruction in response to student readiness, interest, and learning profile in academically diverse classrooms: A review of the literature. Journal for the Education of the Gifted, Vol. 27(2-3), pp. 119-145. Retrieved from https://eric.ed.gov/

Zeng, Y., \& Day, C. (2019). Collaborative teacher professional development in schools in England (UK) and Shanghai (China): cultures, contexts, and tensions. Teachers and teaching, Vol. 25 (3), pp. 379-397. Retrieved from https://scholar.google.com/scholar 